\title{
FRAME ANALYSIS OF THE CONCEPT OF DEATH ACROSS CULTURES
}

\author{
Agnieszka Uberman \\ University of Rzeszów, Poland
}

\begin{abstract}
Uberman, A. (2018). Frame analysis of the concept of death across cultures. In Lege artis. Language yesterday, today, tomorrow. The journal of University of SS Cyril and Methodius in Trnava. Warsaw: De Gruyter Open, 2018, III (1), June 2018, p. 417-447. DOI: 10.2478/lart-2018-0011 ISSN 24538035
\end{abstract}

Abstract: The paper addresses the concept of 'death' and the way it can be presented in the form of a semantic frame. Owing to a considerable diversity of approaches between various cultures and religions, the cognitive model illustrated in the present discussion depicts the European perspective. The analysis helps to establish the elements of the frame together with their lexical exponents employed in language, which are conditioned on the worldview adopted by a particular community.

Key words: cognitive model, linguistic worldview, frame, death, funeral rituals.

\section{Introduction}

The present discussion aims at presenting intricacies of the semantic frame of DEATH. The author's attempt is to show what this cognitive construct entails and how varied those elements can be with respect to diverse cultural backgrounds. For instance, a sequence of events following death can be different in various social groups; hence, the script of [FUNERAL] or [BURYING THE DEAD] will undoubtedly involve dissimilar stages and activities. They will not be considered in detail in the present discussion, but the variations pointed to in section 2. Symbolism and traditions of death as well as in the analysis of the frame will indubitably indicate divergent practices. 
Death is an omnipresent phenomenon therefore it has been recognised in human cultures and languages the world over. For this reason it can be explained in terms of semantic primes representing the core of the meaning, irrespective of the language a given people knows and uses. This approach has been adopted from extensive research originated and developed by Wierzbicka (1996 and later works). Also, since various communities, tribes, societies, nations, and diverse groups of people exhibit certain often varying - viewpoints, the notion of the linguistic worldview will also be referred to and employed in presentation of the overarching theme.

Corpus of language is presented on the basis of available lexicographic sources, drawing most heavily on the data available in one of the most prominent lexical collections, namely the online edition of Oxford English Dictionary. It aims to present parallel as well as divergent points in the traditions observed in various social settings and cultural backgrounds, yet focusing primarily on the perspective of the European culture. The author aims to outline the semantic frame of DEATH, which will naturally involve the presentation of the lexical items making up the aforementioned construct (i.e. the semantic frame of DEATH). Owing to the fact that the concept of death is very extensive and can be described from a number of perspectives (medical, philosophical, psychological, etc.), the present discussion will only touch upon the most salient of its numerous elements. A cross-cultural perspective will be adopted to highlight some traditions, such as funeral rituals, based on the data collected in literature of the subject. Because of the vast scope of the theme, such descriptions shall only be brief in the present analysis.

\section{Symbolism and traditions of death}

Every life ends in death. This is a natural phenomenon no one can escape or avoid. According to an encyclopaedic source, for many peoples death plays a major role in rites of passage, in which it is synonymous with the so-called transition period characterised by regressus ad originem (Żurawski 2007: 749), i.e. the return to the origin, which precedes the social and psychological rebirth and / or revival. Thus, 
understood symbolic death is expressed through silence, darkness, stillness, and / or incompleteness. In European tradition, death is symbolically represented by black whereas in Eastern cultures the colour is white (Kowalski 2007: 625). The black colour, which is related to darkness of the underworld, and the white colour, which in fact stands for the absence of colour both reflect disintegration of forms, loss of definition and the state of lack of diversity, all of which are characteristic of the spirit world or the beyond.

In Medieval times, death was portrayed as an armed woman with bat wings and hawk claws, her hair let down. Another image, which is most typically associated with death is the skeleton wrapped in velvet and holding various masks, which represent diverse images of death. Death is also symbolised ${ }^{1}$ by other numerous imageries, including a skeleton-rider with a sword, a torch or an hourglass, a coffin, a cypress tree, a skull and crossed bones, an Apocalypse rider on a fallow-coloured horse, an extinguished torch, a blown off candle, a shattered column, an urn with some draped fabric, ruins, an ivy wreath, and a sheaf of wheat with a sickle (Żurawski 2007). Kopaliński (2015) expands this collection with a willow, ashes and dust, a bat, a swan song, a mummy, gallows, as well as rigor mortis.

In classical tradition, according to Żurawski (2007), death was portrayed as a young white male accompanied by his black twin representing Dream, both reclining with crossed legs. Slavic peoples used to consider death to be female, while Germanic ones viewed it as male. Yet, in a recent Hollywood film, titled Collateral beauty (2016), the death encountered by the main hero, Howard (Will Smith), is portrayed as an elderly white woman (starring Helen Mirren).

Various cultures offer diverse beliefs and traditional behaviour connected with death, all of which have their origin in different religions. As noted by Kopaliński (2015) or Żurawski (2007), a common motif associated with death is that of a journey into the beyond, which is ingrained in language and present in many figurative expressions 
across languages. Since time immemorial humans have buried their dead, often with numerous utensils and in particular positions. There are also different rites of maintaining contact with late members of families or communities as well as cleansing and protective practices, such as, for instance, covering mirrors, putting up a fire in front of the house, placing water on the return trip from a burial site. Separation rituals include burying the dead, cremation, exposing a dead body to birds of prey, or submersion.

There are numerous superstitions, which vary across cultures. As noted by Chow (2009: 337), some insects (beetles and crickets) together with particular sounds they make, blackbirds as well as crows are considered death omens, and so are dogs howling for no apparent reason or abnormal bird behaviour patterns (flying into a house, tapping on the windows or crying oddly at night). It is believed that windows and doors should be wide open and unlocked in a house when someone is dying. Also, "mirrors are to be turned inward to avoid reflections, and all knots should be untied. There is a belief that if the eyes of the deceased person are open, another death will follow soon" (ibid. 2009: 337).

Once a person dies, their body has to be disposed of. The rituals that are found in human society and observed by different groups of people are not uniform. Green (2009: 265) states that in 1907, Hertz "puzzled over secondary burial". Secondary burial was reported among various groups in Sarawak.

In this practice, bodies of the deceased are stored in large jars buried in the ground. After a time they are disinterred, the bones cleaned, and skulls displayed in the houses of their former owners. Versions of secondary burial are widespread in human societies (the medieval European traffic in sacred relics is an example),

hence, this tradition was claimed to be more than a curiosity. 
Seen from the perspective of cultural anthropology, Hertz classified death as a prolonged process involving many stages and concluding in rebirth. Thus, death was not considered as obliteration and the final stage of life (quoted in Green 2009: 265 267). The anthropologist suggested a three-part model, in which the first part was constituted by relationships between the living and the corpse, the second was formed by body / soul contrast while the third type of relationship is created "between the living and their dead" and it consists in grief, bereavement and memory. Thus, as further noted by Hertz, the processing of the dead body is of crucial importance, i.e. "the first [relationship], the preparation and disposal of a corpse, is foundational; body handling is an indicator of the significance of the deceased in life and an occasion for status display by the surviving family" (Green 2009: 265). Body cleansing and disposal practices also vary among peoples and cultures. For instance, ritual body washing and wrapping are present in Jewish tradition. Cleansing is also essential for Hindus, who bring their dying relatives to Banaras on the river Ganges; for them, however, the fire is the cathartic means instead of water. A strikingly diverse manner of body disposal was practised by the precontact Wari peoples of the Amazon. The way they exhibited respect for the deceased was by cooking and eating portions of the corpse. Green (2009: 266) explains the practice as follows:

ground burial [...] was unacceptable because a buried body in a known location was a remainder of sadness whereas a consumed one was not. Eating was to eradicate memory not to preserve it. [...] this method of body disposal was congruent with Wari notions of personhood, cosmology, expression of grief, and memorization. Personhood for them was a matter of relationships and lifelong reciprocities [...] thus eating the deceased is the final act of sharing, the Wari way of making sense of the existential meaningless that every death implies.

Hence, as can be concluded on the basis of the above data, a seemingly common phenomenon may be viewed and experienced differently by members of diverse communities, cultural backgrounds or religious groups. Together with the evolution of societies, their systems of beliefs as well as traditions and customs have also undergone numerous changes. Death seems to have occupied a significant position in diverse 
cultures, which is reflected by a plethora of rituals and rites devoted to it and observed across different ethnic communities.

However, let us first note that the definition of death itself can be presented from a range of perspectives. For instance, as noted by Metcalf (2006: 127-128):

in Western medicine, there has been an on-going debate about what constitutes death. Technical advances allow patients seriously injured in car crashes, for instance, to be kept alive with machinery that performs bodily functions for them while they have a chance to recover, even such basic functions as breathing. But in several cases, they have not recovered, but fallen into what is evocatively called a "vegetative" state. In what sense is such a person "alive"? The medical answer is that if any brain function persists, in terms of electrical activity in the cortex, the patient is, if not exactly alive, at least not dead. Only an appeal by relatives, followed by a court order, allows doctors legally to turn off the machines.

This clearly shows how complicated the definition may be of the concept and the phenomenon so ubiquitous and unescapable. Nevertheless, the author points out that "such quibbles are beyond the resources of most people in Third World countries, but that does not mean that their definitions of death are any less 'socially constructed' " (Metcalf 2006: 128). As an example, he quotes the Polynesian languages, which share a word mati originally translated by ethnographers as 'dead'. On closer inspection, however, they discovered that "it was possible for someone, usually a senior man, to be alive and also mati" (Metcalf 2006: 128). He continues by explaining that the situation originated at the moment the chief told the tribe members to stop feeding him. "Such a man could not feed himself, but had to be fed because of his great mana" ['spiritual power']. This act was not suicide, however, the chief's motives were usually "to defend the prestige of his chiefly line, his ancestors. When the emaciated chief finally "died", he would be given a funeral in accordance with his standing, but he became mati at the moment when he issued his order" (Metcalf 2006: 128). Hence, for Polynesians death was not synonymous with bodily malfunctioning; it was disconnection from the society of the living.

As noted by Yasien-Esmael and Rubin (2005: 495) with reference to Muslim practices in Israel, "the Islamic approach to death is organized into a set of rituals and communal 
norms that structure the initial response to death, the funeral and the formal mourning periods". The overall statement is true not only of Muslim followers. However, the details of the practices show where the diversities between social, national or religious groups can be, and indeed are, found. Thus, the authors (ibid.) state upon their own observation that

prolonged public expression of grief and ritualized mourning are discouraged in Islamic practice. The society's cultural belief is that prolonged grief and mourning manifest in functioning interfere with a rapid return to living. Resumption of everyday functioning is perceived as normative, religious, and adaptive (Yasien-Esmael 2000). This view is based on and complemented by interpretations that stress a quick return to acceptance of a loss as acceptance of God's will.

In many African beliefs, death is viewed as a part of the natural rhythm of life. Barrett (2009: 21) stresses the fact that

The cyclical view of life regards death as a natural part of life and that each birth constitutes a renewal of life and community. Consistent with this belief, the ancient ritual of passing babies over the casket of a deceased elder is a way of honouring the elder and also honouring the life and death connection that is so important to family and community.

Hence, death exemplifies an intermediate stage in life, which requires a passage rite. Nevertheless, irrespective of the way in which such rites are executed, death is generally seen as tied to life, either that which has just ended, or some form of a future life or afterlife.

\section{Semantic primes related to the concept of death}

Death is inextricably related to life, hence it is describable in terms of and with reference to the end of life or being no longer 'alive', which itself is a semantic prime. According to Wierzbicka (1996: 86), years of research did not allow "to define the concepts of 'life' and 'live' in simpler terms". She adds that

all such attempts are probably futile and [...] when medieval philosophers defined an animal as "vivens sentiens" ('a living thing, a feeling thing') they knew what they were doing: one cannot define (in simpler terms) the concept of 'living', as one cannot define the concept of 'feeling'. On the other 
hand, if we accept that 'life' is a simple, irreducible concept, many other concepts can be defined in terms of it.

In support of the above statement, Wierzbicka (1996: 87) points out that "there are concepts related to death, such as 'die', 'kill', 'murder', 'agony', 'resurrection', 'immortality', 'reincarnation', 'corpse', 'stillborn', and so on, all referring in their meaning to 'living' ". She also provides the following exemplary definition (with the application of Natural Semantic Metalanguage formulas):

"At this time he died. = at this time something happened to him before this, he lived (he was alive) after this, he didn't live (wasn't alive)"

Goddard (1998: 56-57) states that

an ideal NSM semantic analysis (often called an EXPLICATION) is a paraphrase composed in the simplest possible terms, thus avoiding circularity and obscurity. No technical terms, 'fancy words', logical symbols, or abbreviations are allowed in explications, which should contain only simple expressions from ordinary natural language [...]. As a true paraphrase, the explication should be exhaustive; that is, it should faithfully portray the full meaning of the expression being analysed. It is also expected that an explication couched in semantically simple terms will be readily translatable across languages.

The use of semantic primitives does not allow further simplification, as "they are primitive in that they cannot be paraphrased using only other primes - in that sense they are 'indefinable' " (Murphy 2010: 70). Goddard and Wierzbicka note that "semantic primes and their grammar together constitute a kind of mini-language which can be thought of as the 'intersection of all languages'. As such, it is an ideal tool for semantic description" (2014: 12-13).

Individual languages have their own specific grammatical patterns according to which language is produced. Wierzbicka (1996: 112) emphasises the fact that if speakers of diverse languages are to understand meanings expressed by other language users, 
if cross-cultural understanding is possible at all, despite the colossal variation in language structures, there must be a common core of "human understanding" relying not only on some shared or matching lexical items but also on some shared or matching grammatical patterns in which shared lexical items can be used. Arguably, this common core defines a set of "basic sentences" which can be said in any language, and which can be matched across language boundaries, and the grammar of these basic sentences consists in the possible distribution patterns of the "atomic sentences" (that is, the lexical indefinables)

and their combinability as well as co-occurrence. In an attempt to describe and generate the grammar of universal semantic primitives, a set of rules and patterns was proposed. The originally proposed set of semantic primitives (Wierzbicka 1996: 125-126) included 'Existence and Life' with LIVE (ALIVE) considered as "a predicate", which "opens a slot or slots for temporal adjuncts:

These people lived for a long time.

These two people lived at the same time.

This person was alive at that time".

However, "LIVE can also be used without any adjuncts:

These things are living things. (= live?)".

Further studies of semantic primes allowed the researchers to identify the set 'Life' with LIVE and DIE as semantic primes (Goddard 1998: 58), and 'life' and 'death' as their English exponents. Goddard and Wierzbicka (2002: 53) note that LIVE and DIE "have a close affiliation with one another" and they further add that "LIVE implies duration whereas DIE does not". Referring to the English exponents of the primes, they point out that "the semantic relationship between the English alive and LIVE is mediated, as it were, by the word dead. Roughly, 'X is dead = X is not living any more'; and ' $\mathrm{X}$ is alive $=\mathrm{X}$ is not dead' " (ibid. 2002: 54). In Polish, the exponent żyć of the semantic prime LIVE is imperfective, while the exponent umrzeć associated with DIE is perfective. As noted by Wierzbicka (2002: 106), 
the semantic basis of these facts seems clear: life, in contrast to death, cannot be viewed as instantaneous (cf. 'at that very moment, he died' vs. '? at that very moment, he lived'), and it can hardly be viewed as an event (the question 'What happened?' can be answered with 'he died', but hardly with 'he lived'). ${ }^{2}$

Thus, the above addressed semantic primes include LIVE and DIE, whilst their English exponents are 'life' and 'death'. These primes are basic level concepts, which are universal in human languages and cannot be further reduced to simpler notions. Their position at the basic level in reductive paraphrase explications grants them the status of the core of human experience. This feature, in turn, secures their unanimous presence in human cognition as well as expression the world over. Hence, the frame analysis of DEATH can potentially help to establish universal frame elements as well as culture-related or religion-induced variations.

\section{Linguistic worldview}

The way humans understand and perceive the reality is conditioned by a number of phenomena. This perception, or worldview, can be referred to as "an ideological, political, or religious outlook on the world" (Głaz, Donaher \& Łozowski 2013: 14; after Maćkiewicz 1999). The worldview, thus interpreted, has two "modes of existence", namely: "mental (a component of people's consciousness) and an objectification of this abstract mental construct in the form of "traces": art, customs, rituals, gestures, mimicry, social organizations, relationships, and language" (Głaz, Donaher \& Lozowski 2013: 14). The linguistic worldview is therefore subordinate to the worldview as such.

Many linguists agree that the linguistic picture of the world, which is embedded in human languages, is employed to describe the world in which we live with all of its natural laws, human experiences and activities. Bartmiński (2009: 23) defines it as

a language-entrenched interpretation of reality, which can be expressed in the form of judgements about the world, people, things, events. It is an interpretation, not a reflection; it is a portrait without claims to fidelity, not a photograph of real objects. The interpretation is a result of subjective perception and conceptualization of reality performed by the speakers of a given language; thus, it 
is clearly subjective and anthropocentric but also intersubjective (social). It unites people in a given social environment, creates a community of thoughts, feelings and values. It influences (to what extent is a matter of discussion) the perception and understanding of the social situation by a member of the community.

Underhill (2015: 231) describes the linguistic worldview more concisely as the conception of a semantic, anthropological as well as cultural nature.

It is based on the assumption that language codes a certain socially established knowledge of the world and that this knowledge can be reconstructed and verbalized as a set of judgements about people, objects and events. The knowledge results from the subjective perception and conceptualization of reality by the human mind; it is anthropocentric and relativized to languages and cultures.

Hence, depending on the cultural setting and background of a given speech community, this linguistic worldview may differ to a varying extent, and the descriptions produced with its application will naturally yield diverging images.

Underhill (2011:3) also notes that it is hard to undermine the conception stating that "worlds and worldviews are intertwined and that language and thought are related". Numerous linguists believe that "each language system is in itself a conceptual 'world' ", hence "each language system opens up for us 'a whole new world', a world in which the 'objects of understanding', the concepts with which we think and speak, are shaped differently" (ibid.: 4-5). Taking into consideration various aspects of the discussed issue, he claims that at least three dimensions of worldview are interacting, namely:

1. The worldview of the language system, that mode of understanding which provides us with concepts and which organises the relationships between those concepts.

2. The worldview of each cultural mindset, a worldview which paradoxically must take root within a given linguistic worldview but which can migrate between the language systems (as the spread of Catholicism, Protestantism, Buddhism and communism clearly demonstrates).

3. The worldview of the individual which finds its highest expression in the works of great writers who cultivate their language as Tolstoy, Dostoyevsky, Goethe, Shakespeare or Orwell have done.

The above distinctions are in no way to be treated as classifications or individual categories. Instead, they are to be treated as "a means of discerning different conceptions of the relationship between language and thought, between words and 
worldviews" (ibid.: 6). However, the expert provides a taxonomy of "the worldview of the language system and the worldview attributed to writers and individual speakers" (ibid.: 7). Therefore, we can distinguish between:

1. World-perceiving, designating the frameworks of understanding which direct and shade our perception of the world.

2. World-conceiving, designating, the conceptual frameworks which enable us to communicate with others and engage in the discussion of ideas, impressions and feelings.

3. Cultural mindset, designating the worldview specific to a political regime or religion (and the concepts of 'man', 'woman', 'family', 'organisation', 'social stratification', 'social objectives', 'history', 'destiny', and so on, which take their place within the 'logic' of that mindset).

4. Personal world, designating the fairly stable system of concepts which organise and structure the worldview we can attribute to individuals and writers [...].

5. Perspective, designating the fluctuating conceptual and emotional response we have in interacting with the world, whose shape is constantly being reaffirmed and reinvented by each one of us as we ourselves change and develop.

The following brief sketch will point out how the worldviews expressed in different languages are likely to surface. The frame of DEATH embedded in English and in the Western world shall be introduced. It will reflect the Western worldview, and the attempt to show discrepancies between different cultural mindsets (Catholic, Jewish, Muslim, etc.) will also be made with the help of the outline of the related script [BURYING THE DEAD].

\section{Inner structure of the frame of DEATH}

Among the numerous ways of describing the reality, the cognitive constructs (or cognitive models) such as frames and scripts can be named. Frames, as described in expert literature (for instance, Burkhanov 1998; Cruse 1986; Evans 2007; Fillmore \& Atkins 1992; Lakoff \& Johnson 1999; Ungerer \& Schmid 1996; and many others), are complex knowledge structures, which encompass not only culturally-conditioned information, but also descriptions of activities and tools employed in the related processes, their linguistic exponents and elements that are interrelated and mutuallyconditioned. As pointed out by Burkhanov (1998: 85-86), "in the most general terms, 'frame' may be defined as an area of knowledge or a mental plan of action", whereas, Fillmore and Atkins (1992: 76-77) believe that lexical meaning "can be understood 
only with reference to a structured background of experience, beliefs, or practices, constituting a kind of conceptual prerequisite for understanding the meaning". Thus, Burkhanov further explains that "speakers of a given language can be said to know the meaning of a particular lexical item only by first understanding the background frames that motivate the concept that the word $^{3}$ encodes" (1998: 86). Semantic frames provide "an overall conceptual structure defining the semantic relationships among whole "fields" of related concepts and the words that express them. [...] In addition, the conceptual frames that inhabit our cognitive unconscious contribute semantically ${ }^{4}$ to the meanings of words and sentences" (Lakoff \& Johnson 1999: 116), hence a word is defined in relation to the frame in which it is embedded. Evans (2007: 85) summarises a frame as "a schematisation of experience (a knowledge structure), which is represented at the conceptual level and held in long-term memory and which relates elements and entities associated with a particular culturally embedded scene, situation or event from human experience". The cognitive construct under consideration, i.e. frame, has been universally adopted in the analyses of linguistic phenomena and language resources (for instance, Панасенко \& Гуменюк 1995; Панасенко \& Дмитриев 2016; Uberman 2006; 2016; Burkhanov 1999; to mention but a few).

It is essential to stress the fact that frames are related to scripts, which represent "stereotyped sequences of actions that constitute a global event" (Cruse 2006: 156). As originally defined by Shank and Abelson (1977: 41):

A script is a structure that describes appropriate sequences of events in a particular context. A script is made up of slots and requirements about what can fill those slots. The structure is an interconnected whole, and what is in one slot affects what can be in another. Scripts handle stylised everyday situations. [...] Thus a script is a predetermined, stereotyped sequence of actions that defines a well-known situation.

Burkhanov (1999: 189) stresses the fact that 'scripts' can be viewed as either included in the understanding of 'frames' when the latter are viewed as covering both events and situations, or as a discrete construct when a 'frame' is regarded only as "the mental representation of prototypical scenes and static situations". Evidently, scripts can show 
discrepancies from culture to culture (Tarone \& Yule 1989: 89) where various elements present in one culture will be viewed as incongruous in another. Nevertheless, they "encode a language user's knowledge of the actions that are undertaken in a culturally stereotypic situation" (Uberman 2006: 46), which is apparent with reference to various corpse treatment procedures or funerary traditions, some of which have already been addressed.

For the purpose of the present analysis, scripts will be viewed as included in the interpretation and representation of a frame. This construct will be employed in the discussion to follow in order to outline the scope of the discussed and analysed area of knowledge as well as linguistic reality.

Referring to various tools employed in the cognitive-linguistic description of lexical meanings Kuźniak (2018: 108) notes that in order to "maintain the declaratory revolutionary approach to the study of meaning, the focus must be laid onto the aspect of real dynamicity of emergent meaning in ongoing discourse. This may be done at the expense of abandoning the ambition to extrapolate local context-sensitive conclusions onto global, generalized plane of interpretation". This however, cannot be easily done with reference to culture-specific denotations, which are not easily construed by nonmembers of a specific group or community.

The concept of death, as well as the processes of dying have been coped with and described by, among others, such professional groups as physicians, philosophers, religious leaders, poets, writers, but as a natural phenomenon it can also be subject to linguistic analysis both in terms of the lexical exponents employed in language as well as the cognitive constructs for which it might be a focal element. The attempt will be made in the following discussion to outline the elements of the frame of DEATH, seen from the perspective of the European tradition. Moreover, the prototypical association of death, i.e. for natural causes and not self-inflicted or conditioned by third parties, will be exemplified. It is important to note that particular types or causes of death, such 
as suicide, murder, mercy killing, etc., shall not be taken into consideration for the fact that they are not treated as prototypical. It is also necessary to highlight that on numerous occasions euphemisms are employed in place of those vocabulary items, which directly address the concept of death and related phenomena ${ }^{5}$. The definitions quoted in the following discussion are based on Oxford English Dictionary (s.a.).

It is somewhat of a cliché, but it is impossible to disagree with Bleyen (2009: 340) who states that: "Death is generally considered the only certainty of life. At the same time, however, no matter where or when one is living, death is also regarded the ultimate mystery of human experience." What is also important to highlight is the fact that ways of conceptualising and describing death are diversely approached and treated in different cultures. In line with the concept as well as the discussion of semantic primes LIVE and DIE presented by Wierzbicka (1996), the interrelation of life and death, however, is essential for the interpretation of the conception of death; "understanding death inevitably involves defining life: the concepts of death and life are dynamically related to one another" (Bleyen 2009: 340). Numerous researchers, (such as for instance Bleyen 2009: 341-342), agree that death is an indicator of life revealing central social processes and cultural values. Moreover, death is often considered the mirror of life because life cannot exist without death and vice versa. Whether in a dichotomous or hybrid relationship, death is defined in terms of life.

Together with the development of medical sciences, the definitions of death have also evolved. The borderline separating life from death was initially recognised with the last breath, i.e. when breathing stopped. Later on, the heart stopping and most recently the brain death have been considered the evidence of death taking over life.

OED defines death as "the act or fact of dying; the end of life; the permanent cessation of the functions of a person, animal, plant, or other organism. Also: an instance of this; (with specification) a manner of dying". It is a process that can be accidental - when no one expects it to take place, "caused by an unexpected or chance incident; occurring 
as the unintended consequence of an action"; natural - "resulting from old age or disease, not brought about by accident, violence, poison, etc."; sudden - literally this would imply an action, event or condition "happening or coming without warning or premonition; taking place or appearing all at once" (OED). However, the phrase sudden death (quick death) also has a metaphorical meaning; it is a slang term, which refers to "a single toss used to decide an issue; hence in Lawn Tennis, a game played to break the tie; also in general sporting use, designating an additional competition or period of extra time in which the first to concede a game or score is immediately eliminated"; or in American English "a potent alcoholic drink" (OED). Death can also come prematurely in infancy as sudden infant death syndrome, which describes "a condition characterized by the sudden, unexpected, and unexplained death of an apparently healthy infant". However, when a child is born dead, i.e. "born lifeless, dead at birth", it is referred to as a stillborn child; the delivery results in a stillbirth (OED).

When a person dies, at whatever time of their life, the family and closest relatives as well as friends can experience a number of feelings. Frequently they are sad, they feel pain, sorrow, grief and, often, despair. They suffer emotionally and often physically, too. Rarely does someone's death bring about relief. Irrespective of the fact if death is expected and awaited, when a person has been in great pain or suffering, it is still difficult to prepare for and accept the moment of parting.

Customarily community members are informed about someone's death by means of obituaries, i.e. "a record or announcement of a death, esp. in a newspaper or similar publication; (in later use) (also) spec. an appreciation appearing in a newspaper or news broadcast, of an eminent or well-known person who has recently died, typically including a brief biography" (OED). Obituary is published in a newspaper or placed where many people can see it, such as on a notice board, etc. It often includes some religious symbols showing the religious denomination of the deceased. Most societies have some manner of announcing the death of one of its members. It is interesting to note that in pre-media times in England, "before newspapers and printed death notices, 
town criers, later known as "death criers", announced the deaths of prominent persons. Dressed in black, often with a death's head and crossbones printed on the fronts and backs of their robes and sometimes with the bell in hand, they walked and cried out their messages" (Williams 2003: 694).

Traditionally, a dead body needs to be buried. It is placed in a coffin - "the box or chest in which a corpse is enclosed for burial", and buried in a grave, i.e. "a place of burial; an excavation in the earth for the reception of a corpse" in a cemetery / graveyard / churchyard during a funeral - "the ceremonies connected with the burial (or cremation, etc.) of the body of a dead person; obsequies; a burial (or its equivalent) with the attendant observances" (OED). If a family decides to cremate the dead body, i.e. "to consume by fire, to burn; spec. to reduce (a corpse) to ashes" (OED), the remains are placed in an urn and the ceremony of urn-burying follows. The corpse placed in a coffin or urn is displayed in a church or chapel prior to the funeral mass or a funeral service. Unlike a Western European tradition, in Poland funeral homes are not as frequently used. However, this is the issue of religion as well. Hence, depending on the denomination of both the deceased and his / her family, the funeral service (exemplified by the script [BURYING THE DEAD]) can be carried out differently, and general elements of the frame of DEATH will vary in certain cultureand religion-induced details.

Cemetery is defined as "a burial-ground generally; now esp. a large public park or ground laid out expressly for the internment of the dead, and not being the 'yard' of any church", graveyard is "a burial-ground", while a churchyard is described as "the enclosed piece of consecrated ground in which a church stands, formerly almost universally used as a burial ground for the parish or district, and occasionally still used for Christian burials or memorials when space permits" (OED). In Poland, many burial sites are still in the vicinity of the church / chapel or are owned by Church, hence they are not of park-like nature for the fact that they are consecrated. Nevertheless, the 
choice of a burial site is again conditioned by the religion in which the deceased were brought up or according to which they lived and wish to be buried.

In a Roman Catholic tradition, the burial ceremony is preceded by a mass. The coffin / urn in placed in the front and funeral candles are lit. Around and in front of the coffin / urn wreaths of flowers are placed. Prayers are said, sometimes speeches are given to commemorate the departed person, or, in general, funeral honours / last honours, i.e. "the observances of respect usual at the burial of the dead" (OED) are paid.

When the service is over, the coffin is carried out of the church / chapel / funeral home and taken to the tomb in a funeral procession. The coffin is carried out by pallbearers - people "helping to carry or officially escorting the coffin at a funeral", family members or friends - and often placed in a hearse, i.e. "a carriage or car constructed for carrying a coffin at a funeral", which takes it to the grave. The coffin is lowered into the grave and covered by a grave-cover ("a stone slab covering a grave"). In case the ashes are placed in an urn, it is either buried in the grave or placed in a niche in a columbarium, i.e. "a subterranean sepulchre, having in its walls niches or holes for cinerary urns; also one of these niches or recesses" (OED).

When a family member dies, the remaining family members are in mourning. Mourning is generally considered as "grieving caused by the death of a person". It is "the action of feeling or expressing sorrow for the death of a person; sorrow or grief for a deceased person; an instance of this; an expression of grief or lament for a deceased person". However, it also refers to "the conventional or ceremonial manifestation of sorrow for the death of a person; esp. the wearing of clothes associated with death (in Western society usually black). Also: the period during which such clothes are worn" (OED).

The phrase in mourning describes "sorrowing or grieving for the death of a person, esp. in the period of the conventional or ceremonial manifestation of sorrow" or 
"wearing clothes or covered with the draperies customarily indicative of bereavement" (OED). The dominating mourning colour in Europe is black (black mourning clothes) and the length of the mourning period depends on the relation towards the deceased person; however, there are no set periods prescribed by the Church (customarily, in Poland a person goes into mourning for a year to honour a deceased husband / wife or a parent, half a year for a close relative and they are out of mourning three months after the death of a more distant one).

In contrast to the above, Standaert (2008) provides a detailed description of funerary practices in China (compare Crowder 2003: 673-686). In contrast to the European tradition largely influenced by the Roman Catholic observances and inflicted sets of rules, "Chinese funerals were family rituals [...]; the European were ecclesiastical rituals" (Standaert 2008: 34). The typical colour worn by family members of the deceased is black, whereas in Chinese tradition the colour is white, and also the deceased is dressed in "multiple white "grave" or "longevity" jackets" (Crowder 2003: 684). Burying of the dead body takes place within a different time range (much later in case of the Chinese tradition). Various differences in this respect are noted in diverse cultural or religious communities. For instance, as noted by Metcalf (2006: 175-176), "no society lacks death rituals. No one puts corpses out with the trash, and gets on with everyday affairs". Nevertheless, some very simple rituals can be observed, such as the instance of Kalahari Bushmen who "leave a corpse where it lies, but immediately abandon the campsite, not returning for years. Without burial, it is left to corruption and wild animals to dispose of the corpse". Such an attitude is impossible in Western tradition, where the deceased are respected and their remains are either buried whole or cremated. Other mortuary rites, which may be surprising for non-residents are observed in Borneo and elsewhere. According to Metcalf (2006: 176), they last for extended periods of time, "for months or even years, and involve moving corpses from a place of temporary storage to a final grand mausoleum". 
Differences can be noted for various cultures and, what is closely related with them, diverse language communities. Referring to the American ways of responding to death Thursby (2006: 1) points out that

the American character commonly adapts old ways to new, and the United States, a complex civilization made up of its own indigenous people and multitude of cultures from around the world, has reinvented the response to death. Rather than a space of time with emphasis on separation, death and the funerary rituals surrounding it have become a place for renewal and reaffirmed connectedness between family and friends of the deceased.

A different approach is practised by Aboriginal peoples of Australia. The way a dead body is treated and disposed of reflects the "Aboriginal view of death as a transition through which a person moves to another phase of existence" (Venbrux \& Tonnaer 2009: 88). The spirit of the late relative or community member needs to be chased away from the world of the living to the world of the dead, which might entail partial or thorough destruction of not only the deceased person's remains but also his / her material goods.

Considering the above, in an outline of the script of [BURYING THE DEAD] seen from diverse cultural perspectives, various elements would be present and only some would be overlapping. These include funerary rites and certain procedures, which are irreversibly connected with the passage from the world of the living to the world of the dead. For instance, in Western tradition itself, either the body would be placed in a coffin or casket, or the remains would be placed in an urn. Those containers, in turn, would be placed in the ground, i.e. buried proper or, in case of the urn, it might also be placed in a columbarium. Such elements would be absent if the script were to be drawn for American Indian tribes (see Cox 2003), Hindus (see Rambachan 2003), or Aborigines. Funerary traditions cultivated in Japan (see Suzuki 2003) or China (see Crowder 2003) are also quite complex and entail various activities and practices. The script would assume a different form and include still other elements for Jews (see Schindler 2003) or Muslims (see Sultan 2003). In Muslim tradition, a coffin is not used 
for burial. Sultan (ibid.: 651-652) states that the corpse is wrapped in a shroud and placed directly in a 4 to 6 -feet deep grave in the position facing Mecca.

In case of some cultures or communities it is difficult to talk of the burying practices at all, as corpses can be preserved. Bolt (2009: 110) notes such forms of body disposition as embalming and mummification, body donation to science, plastination (it is a technique of preservation, which "consists of replacing the natural body fluids with a plastic to preserve the tissues, which makes it possible to display the body in any desired position"), cryonics, and mortuary cannibalism. Burial at sea is another possibility of disposing of the dead body. However, attitudes towards this form of corpse removal vary cross-culturally. Steward (2009: 123) highlights the fact that

some cultures view water as the proper place for the dead, whereas others see it only as a place of last resort or as the place to dispose of criminals or other social outcasts. The former attitude is probably best exemplified by the Hindu belief that the river Ganges is a sacred place that will take the dead to heaven.

Also, the difference between ground burial and burial at sea is that by being placed in water the body is not buried as such. During "a ritual of separation in which the deceased is symbolically removed from the world of the living and placed in the realm of the dead" (ibid.: 124), performed in case of land burial, the corpse is positioned inside a grave in the ground, and the soil placed over it constitutes not only a symbolic but also a real barrier between the two worlds, those of the living and the dead.

Multiple differences can be illustrated for traditions practised by communities the world over. Diversity is also noted in the way prayers are said and mourning is observed. Positioning the body in the grave or some other place of eternal rest is another area where various procedures are employed. Hence, it is apparent that a single universal script cannot be designed. Nevertheless, irrespective of the diversity of practices and rituals, all cultures universally pay respect to their ancestors, in one form or another. 
Another essential difference between diverse cultural and religious groups is the way cemeteries are perceived and treated. As noted by MacLean and Williams (2009: 168), "the word cemetery is derived from the Greek word for the sleeping chamber, as the ancient Greeks believed that the dead were temporarily resting, awaiting the Day of Judgement when chambers would be emptied". Such is also the origin of the common DEATH IS SLEEP metaphor so recurrently represented in language (compare Uberman 2016; 2018).

In Christian tradition, cemeteries are places of solemn memory of the late beloved, flowers are brought and candles are lit to commemorate ancestors, other relatives or friends. In Jewish tradition, as noted by MacLean and Williams (2009), a cemetery is considered Jewish if it is used and identified as exclusively for Jews, and separate entrance gates are provided for Jews and non-Jews. Customarily, a tombstone known as matzeivah, is placed at the head of the grave as a tribute to the deceased. Unlike Christian tradition of bringing flowers, pebbles are left on the tombstones as a token of memory. Muslim cemeteries are not easily identified as such, owing to the fact that they contain few markers across open areas of space. Unlike Christian cemeteries, in Muslim ones distinguishable grave markers or tombstones are not typically used. MacLean and Williams (ibid.: 170) state that

immediately upon death a two-stage cleansing ritual is performed with quiet reverence of samesex family members. The body is arranged in a sleeping position, then wrapped in cloth, three layers for men and five layers for women. There is one exception to this preparation. In the case of martyrs [...] the body is not washed and is buried in the same attire worn upon death.

Even though women are not prohibited from attending a funeral, it is typically a male activity. Women, however, are not permitted to carry the body or escort it to the gravesite. Such restrictions are not present in Christian funerary procedures, hence Muslin-specific elements would not be included in a script characteristic of a different cultural background or a religious group. 
In Mexican cemeteries the joyous rather that overly solemn character is reflected in the typical grave decorations including colourful notes, cards, animated balloons, toys, canned drinks or personal possessions. The crosses are also frequently painted or wrapped in bright colours (ibid.: 171).

Native American funerary rituals are as diverse as the tribes themselves, however, old traditions are being steadily replaced by those influenced by the contemporary society and living. Nevertheless, MacLean and Williams (ibid.: 172) point out that "some tribes are known to have placed their dead on above-ground scaffolds or in trees from which bones were gathered and deposited in earth pits. Some tribes practiced cremation; other buried their dead in the floors of their houses, and some built spirit houses." Irrespective of the variations in funerary procedures, most tribes buried valuables together with dead bodies to ensure "a smooth transition into the spirit world". Relatively remote tribes tend to continue longstanding practices such as covering the graves with traditional tribal blankets, wrapping the bodies either with blankets or in special skin robes, placing prayer ribbons or colourful prayer sticks at the burial site to enable the late tribe members to enter the spirit world.

\section{Conclusions}

It can be concluded from the above outline of the considered frame of DEATH (as well as the reference to the possible frame-related script) that some of its elements are culture-dependent. In fact, they are also religion-dependent, as the above described sketch refers to European tradition, which is unquestionably distinct from burial rites preserved and observed by members of other religious communities, irrespective of their nationality. The world over, these rituals are as diverse as ranging from very solemn to joyous, which can include instances of dancing or other festivities, such as, for instance, in Mexican culture. In contemporary Taiwan, employment of stripteasers is supposed to encourage people to take part in a funeral and to offer entertainment for guests. 
Numerous diversities can be noted not only with reference to the elements constituting the frame but also to its component parts, such as tools employed, practices observed, and sequences of activities described, for instance, by means of scripts.

Obviously, the above-outlined description is not exhaustive as there might be other elements that have not been considered in the discussion. As pointed out earlier, a certain perspective has been adopted for the presentation of the analysed cognitive construct. However, it is essential to mention that particular regional varieties can also be found. Polish people are predominantly Roman Catholic, nevertheless, in various areas of the country specific elements of the ceremony will be present, which are not to be found elsewhere (Podhale - the Tatra Mountains area, Pomerania, Podlasie, etc.). Similarly to other cultures, Polish folklore abounds in numerous superstitions and beliefs connected with death, which are also diversified according to a region ${ }^{6}$. The same is true of other nations where regional diversity can be also exhibited by the rituals and observances practised by their inhabitants.

It has to be noted that the language associated with the above-outlined frame is very productive in terms of generating figurative expressions ${ }^{7}$ and metaphors. They represent and reflect the repertoire of beliefs, traditions, and customs observed by a given national or, more locally, a regional community as well as the worldview expressed by and in their language. Any frame, expressed in any language, as a knowledge structure, represents a conceptual system and a worldview adopted by a particular language community. However, within this language community, as illustrated by the above-presented cognitive construct, differences will be apparent if certain variables are at play. In the case of the discussed frame of DEATH, religious beliefs and practices should be considered, as the diversity in religious denominations or cultural backgrounds will result in the diversity of frame elements. Some of those frame elements will be universal, while others will be specific for a set group. Nevertheless, one thing remains unchanged: nothing is certain but death and taxes. 


\section{Notes and abbreviations}

1. The topic of death symbolism is discussed in greater detail in Uberman $(2016 ; 2018)$.

2. For further detailed discussion on English semantic primes see Goddard and Wierzbicka (2002); for Polish ones consult Wierzbicka (2002).

3. Italics have been introduced by the original author.

4. Italics have been introduced by the original authors.

5. For a short discussion of the euphemism related to the elements of the frame of DEATH see Uberman (2018).

6. See, for instance, a documentary by Szumowska (2006) A czego tu się bać? dealing with the issues of death, i.e. beliefs, traditions and rituals in Podlasie, the northeastern region of Poland.

7. For detailed discussion of figurative death-related language see Uberman (2016; 2018).

OED - Oxford English Dictionary

\section{References}

Barrett, R.K. (2009). African beliefs and traditions. In Encyclopaedia of death and the human experience. Bryant, C.D. \& Peck, D.L. (eds.). Thousand Oaks: Sage Publications, p. 19-22.

Bartmiński, J. (2009). Aspects of cognitive ethnolinguistics. London-Oakville: Equinox Publishing.

Bleyen, J. (2009). Defining and conceptualizing death. In Encyclopaedia of death and the human experience. Bryant, C.D. \& Peck, D.L. (eds.). Thousand Oaks: Sage Publications, p. 340-342.

Bolt, S. (2009). Body disposition. In Encyclopaedia of death and the human experience. Bryant, C.D. \& Peck, D.L. (eds.). Thousand Oaks: Sage Publications, p. 107-111.

Burkhanov, I. (1998). Lexicography. A dictionary of basic terminology. Rzeszów: Wydawnictwo Wyższej Szkoły Pedagogicznej. 
Burkhanov, I. (1999). Linguistic foundations of ideography. Rzeszów: Wydawnictwo Wyższej Szkoły Pedagogicznej.

Chow, A.Y.M. (2009). Death superstitions. In Encyclopaedia of death and the human experience. Bryant, C.D. \& Peck, D.L. (eds.). Thousand Oaks: Sage Publications, p. 336-338.

Collateral beauty (written by Allan Loeb: Warner Bros; directed by David Frankel; premiere in New York City, USA: December 12, 2016).

Cox, G.R. (2003). The native American way of death. In Handbook of death and dying. Bryant, C.D. (ed.). Thousand Oaks: Sage Publications, p. 631-639.

Crowder, L.S. (2003). The Taoist (Chinese) way of death. In Handbook of death and dying. Bryant, C.D. (ed.). Thousand Oaks: Sage Publications, p. 673-686.

Cruse, D.A. (1986). Lexical semantics. Cambridge: Cambridge University Press.

Cruse, A. (2006). A glossary of semantics and pragmatics. Edinburgh: Edinburgh University Press.

Evans, V. (2007). A glossary of cognitive linguistics. Edinburgh: Edinburgh University Press.

Fillmore, C.J. \& Atkins, B.T. (1992). Toward a frame-based lexicon: The semantics of RISK and its neighbors. In Frames, fields, and contrasts: New essays in semantic and lexical organization. Lehrer, A. \& Kittay, E.F. (eds.). Hillsdale: Lawrence Erlbaum, p. 75-102.

Głaz, A., Donaher, D.S. \& Łozowski, P. (2013). The linguistic worldview. Ethnolinguistics, cognition, and culture. London: Versita.

Goddard, C. (1998). Semantic analysis: A practical introduction. Oxford: Oxford University Press.

Goddard, C. \& Wierzbicka, A. (2002). Semantic primes and universal grammar. In Meaning and universal grammar: Theory and empirical findings. Goddard, C. \& Wierzbicka, A. (eds.). Amsterdam-Philadelphia: John Benjamins Publishing Company, vol. I, p. 41-85.

Goddard, C. \& Wierzbicka, A. (2014). Words and meanings. Lexical semantics across domains, languages, and cultures. Oxford: Oxford University Press. 
Green, J.W. (2009). Death, anthropological perspectives. In Encyclopedia of death and the human experience. Bryant, C.D. \& Peck, D.L. (eds.). Thousand Oaks: Sage Publications, p. 265-269.

Kopaliński, W. (2015). Słownik symboli. Warszawa: Oficyna Wydawnicza RYTM.

Kowalski, P. (2007). Kultura magiczna. Omen, przesąd, znaczenie. Warszawa: Wydawnictwo Naukowe PWN.

Kuźniak, M. (2018). Hot issues in cognitive linguistics. In Language in the new millennium: Applied-linguistic and cognitive-linguistic considerations. Uberman, A. \& Dick-Bursztyn, M. (eds.). Berlin: Peter Lang, p. 95-116.

Lakoff, G. \& Johnson, M. (1999). Philosophy in the flesh. The embodied mind and its challenge to Western thought. New York: Basic Books.

MacLean, V.M. \& Williams, J.E. (2009). Cemeteries. In Encyclopedia of death and the human experience. Bryant, C.D. \& Peck, D.L. (eds.). Thousand Oaks: Sage Publications, p. 168-173.

Maćkiewicz, J. (1999). Co to jest "językowy obraz świata"? In Etnolingwistyka, 11, p. 7-24.

Metcalf, P. (2006). Anthropology: The basics. London-New York: Routledge. Murphy, M.L. (2010). Lexical meaning. Cambridge: Cambridge University Press.

Oxford English dictionary. Available at: www.oed.com

Panasenko, N. \& Dmytriiev, Ya. (2016). Frame analysis of American facetious songs. / Panasenko N., Dmytriyev Ya. Frejmovyj analiz amerikanskikh shutochnykh pesen. / Панасенко Н., Дмитриев Я. Фреймовый анализ американских шуточных песен. In Conference materials "Science and education: A new dimension". Philology, IV (19), 84, Budapest, p. 35-40.

Panasenko, N.I. \& Gumenyuk, A.V. (1995). The notion of frame as a means of knowledge representation in linguistics and computer science. In Problems of business. Collection of scientific papers. Cherkasy: Institute of Business Management, I, p. 6167. / Panasenko N.I., Gumenyuk A.V. Ponyatie frejma kak sposoba predstavleniya znanij v lingvistike i informatike. In Problemy biznesa. Nauchno-metodicheskij sbornik. Cherkassy: Institut upravleniya biznesom, I, s. 61-67. / Панасенко Н.И., 
Гуменюк А.В. Понятие фрейма как способа представлений знания в лингвистике и информатике. In Проблемы бизнеса. Научно-методический сборник. Черкассы: Институт управления бизнесом, I, с. 61-67.

Rambachan, A. (2003). The Hindu way of death. In Handbook of death and dying. Bryant, C.D. (ed.). Thousand Oaks: Sage Publications, p. 640-648.

Schindler, R. (2003). The Jewish way of death. In Handbook of death and dying. Bryant, C.D. (ed.). Thousand Oaks: Sage Publications, p. 687-693.

Shank, R.C. \& Abelson, R.P. (1977). Scripts, plans, goals and understanding. Hillsdale: Lawrence Earlbaum.

Standaert, N. (2008). The interweaving of rituals: Funerals in the cultural exchange between China and Europe. Seattle: University of Washington Press.

Steward, D.J. (2009). Burial at sea. In Encyclopedia of death and the human experience. Bryant, C.D. \& Peck, D.L. (eds.). Thousand Oaks: Sage Publications, p. 123-125.

Sultan, D.H. (2003). The Muslim way of death. In Handbook of death and dying. Bryant, C.D. (ed.). Thousand Oaks: Sage Publications, p. 649-655.

Suzuki, H. (2003). The Japanese way of death. In Handbook of death and dying. Bryant, C.D. (ed.). Thousand Oaks: Sage Publications, p. 656-672.

Szumowska, M. (2006). A czego tu się bać? (a documentary). Available at: http://www.filmweb.pl/film/A+czego+tu+si\%C4\%99+ba\%C4\%87-2006-341467 and https://www.youtube.com/watch?v=waNkeaAH5ho

Tarone, E. \& Yule, G. (1989). Focus on the language learner. Oxford: Oxford University Press.

Thursby, J.S. (2006). Funeral festivals in America: rituals for the living. Lexington: The University Press of Kentucky.

Uberman, A. (2006). Modelling the English lexicon in applied linguistics. Rzeszów: Wydawnictwo Uniwersytetu Rzeszowskiego.

Uberman, A. (2016). Death in metaphorical language. In Lege artis. Language yesterday, today, tomorrow, vol. I (2), p. 171-211. DOI: 10.1515/lart-2016-0013 ISSN 2453-8035. 
Uberman, A. (2018). Avoiding to name the unavoidable: Euphemisms for the elements of the frame of DEATH. In Language in the new millennium: Applied-linguistic and cognitive-linguistic considerations. Uberman, A. \& Dick-Bursztyn, M. (eds.). Berlin: Peter Lang, p. 179-190.

Underhill, J.W. (2011). Creating worldviews: Metaphor, ideology and language. Edinburgh: Edinburgh University Press.

Underhill, J.W. (2015). Ethnolinguistics and cultural concepts: Truth, love, hate and war. Cambridge: Cambridge University Press.

Ungerer, F. \& Schmid, H.J. (1996). An introduction to cognitive linguistics. LondonNew York: Longman.

Venbrux, E. \& Tonnaer, A. (2009). Australian Aboriginal beliefs and traditions. In Encyclopedia of death and the human experience. Bryant, C.D. \& Peck, D.L. (eds.). Thousand Oaks: Sage Publications, p. 86-89.

Wierzbicka, A. (1996). Semantics: Primes and universals. Oxford-New York: Oxford University Press.

Wierzbicka, A. (2002). Semantic primes and universal grammar in Polish. In Meaning and universal grammar: Theory and empirical findings. Goddard, C. \& Wierzbicka, A. (eds.). Amsterdam-Philadelphia: John Benjamins Publishing Company, vol II, p. 65-144.

Williams, J.E. (2003). Obituaries. In Handbook of death and dying. Bryant, C.D. (ed.). Thousand Oaks: Sage Publications, p. 694-702.

Yasien-Esmael, H. \& Rubin, S.S. (2005). The meaning structures of Muslim bereavements in Israel: religious traditions, mourning practices, and human experience. In Death studies, 29, p. 495-518. DOI: 10.1080/07481180590962668.

Obyczaje, języki, ludy świata. Encyklopedia PWN. (2007). Żurawski, S. (ed.). Warszawa: Wydawnictwo Naukowe PWN. 


\begin{tabular}{|l|l|}
\hline \multicolumn{1}{|c|}{ Contact data } \\
Agnieszka Uberman, \\
dr hab. prof. UR, \\
Associate Professor, \\
Institute of English \\
Studies, University of \\
Rzeszów, al. mjr. W. \\
Kopisto 2B; 35-315 \\
Rzeszów, Poland; \\
e-mail: \\
ag.uberman@wp.pl
\end{tabular}

\section{Résumé}

The discussion focuses primarily on description of cognitive models such as frames and scripts employed in organising lexical knowledge exemplified here by lexicon related to death. Symbolism and traditions of death, which are present in various cultures are briefly outlined. The concept of death is closely linked to that of life and this interrelation is also reflected in language. Semantic primes LIVE and DIE clearly show that as primary concepts universally present in human languages they constitute basic level concepts and cannot be reduced to more atomic meanings. Interpretation of the reality a given society lives in is conditioned by its adopted worldview, which is also reflected in language used by a specific language community employed for the expression of perceptions and conceptualisations of the reality. In further discussion, attention is focused on cognitive models, such as frames and scripts, which enable language users to account for knowledge structures and conceptual relations of underlying lexical meanings. The objective of the present analysis is to establish elements of the semantic frame of DEATH, hence its various components are noted and discussed. Elements constituting this frame are depicted from the European tradition point of view. Selected elements from other cultural backgrounds are presented in order to show how these parameters affect the scope of the analysed cognitive construct. A related script is also mentioned together with diverse funeral rituals; however, owing to a considerable discrepancy within the cross-cultural 
perspective, it is not fully designed. It is stressed that the cultural background influences the worldview a particular community adopts in order to interpret the reality in which they live. It also affects linguistic means a language user has at his / her disposal and employs in daily communication or interpretation of world phenomena.

Key words: cognitive model, linguistic worldview, frame, death, funeral rituals.

Article was received by the editorial board 03.03.18;

Reviewed 23.03.18. and 03.04.18.

Similarity Index 15\% 